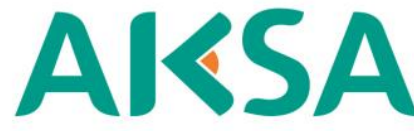

JURNAL DESAIN KOMUNIKASI VISUAL
AKSA JURNAL DESAIN KOMUNIKASI VISUAL

ISSN: 2615-1111 (online)

Available online at:

http://jurnalaksa.stsrdvisi.ac.id

\title{
Pengaruh Teori Seni Barat Dalam Desain Iklan
}

\author{
Budi Yuwono \\ Sekolah Tinggi Seni Rupa dan Desain Visi Indonesia \\ E-mail: budi.ccline@gmail.com
}

\section{ARTICLE INFO}

Article history:

Received: 12 Mei 2018

Revised: 21 Mei 2018

Accepted: 28 Mei 2018

\section{Keywords:}

Art theory

Aesthetic

Ads

Visual communication

\begin{abstract}
Aesthetic has become a clear barometer to measure the beauty value of an artwork. It has been going from the classical era with a realistic style until the modern era which more directed to the applied art. Despite the advancement of the nowadays digital age, an artwork will taste bland when it ignoring these universal basic principles. Those principles are increasingly needed when an artwork turned into a message medium from communicator to communicant.

Advertising design is an applied art, where on one hand it should consider the value of beauty of the ad to attract and seize people's attention. But on the other hand, advertising is a medium of visual communication. If the message is submitted by the advertiser and the media is received differently by the target goal, then the communication will failed. Thus the role of art theory as a universal principle need to be applied in ad designing. The application of the art theory must be tailored to the conveyed message and adapted to the present approach.
\end{abstract}

\section{PENDAHULUAN}

Pemahaman bahwa karya seni adalah hanya dilakukan oleh dan untuk manusia, telah memicu berbagai macam upaya agar karya seni tersebut seindah mungkin. Pada tataran ini, sebagus dan seindah apapun karya Tuhan, maka tidak bisa disebut sebagai karya seni. Sebuah karya bisa disebut sebagai karya seni ketika sudah dipublikasikan yaitu dengan cara dihadirkan atau dipertontonkan dihadapan masyarakat. Dengan semakin menipisnya batasan antara masingmasing cabang seni, maka konsekuensinya teori seni menjadi semakin berkembang. Hal ini juga dirasakan di Indonesia. Dimana percepatan peradaban mengalami ketertinggalan jika dibanding peradaban di Barat. Misalnya kemapanan seni lukis Indonesia yang belum mencapai tataran keberhasilan sudah diporak-porandakan oleh gagasan modernisme yang membuahkan seni alternatif, dengan munculnya seni konsep (conseptual art): "Instalation Art", dan "Performance Art", yang pernah menjamur di pelosok kampus perguruan tinggi seni sekitar 1993-1996. 
Kemudian muncul berbagai alternatif semacam "kolaborasi” sebagai mode 1996/1997. Bersama itu pula seni lukis konvensional dengan berbagai gaya menghiasi galeri-galeri, yang bukan lagi sebagai bentuk apresiasi terhadap masyarakat, tetapi merupakan bisnis alternatif investasi.

Untuk dapat mengetahui lebih jelas tentang perjalanan Teori Seni, kita tidak bisa mengabaikan gejolak peradaban yang terjadi di Barat, dengan sederet periodisasi sejarah seninya.

\section{METODE}

Metode yang digunakan dalam penelitian ini merupakan metode kualitatif deskriptif. Metode ini digunakan untuk memberikan deksripsi maupun eksplanasi secara naratif.

\section{PEMBAHASAN}

\subsection{Teori Seni Jaman Klasik}

Jaman Klasik, atau Jaman Yunani, ada juga yang menyebutnya dengan Jaman Romawi, adalah peradaban yang terjadi pada sekitar abad 7, 8 dan 9 masehi. Karya seni pada jaman ini kebanyakan memiliki fungsi untuk pemujaan, sebagai akibat belum berkembangnya agama. Teori mimesis (peniruan) pertama kali muncul di abad ini sebagai upaya untuk mencontoh alam maupun mahluk semirip mungkin. Sehingga pada jaman tersebut, proporsi menjadi wajib hukumnya. Keterkaitan pengertian antara keindahan, kebeneran dan kebaikan ini tentu menyumbangkan ciri tertentu pada karakterisasi Yunani Antik atas masalah penentuan nilai estetis. Keterkaitan itulah yang tertangkap dalam konsep summetria, atau 'kesetangkupan' (symmetry) dalam bahasa Yunani. (Suryajaya, 2016:30). Maka tidak bisa dipungkiri, karya-karya seni pada jaman tersebut cenderung bergaya simetris. Beberapa tokoh pada Jaman Klasik yang temuan-temuannya mengilhami beberapa seniman dan ilmuwan pada jaman sesudahnya adalah:

\subsubsection{Protagoras (490-420 SM)}

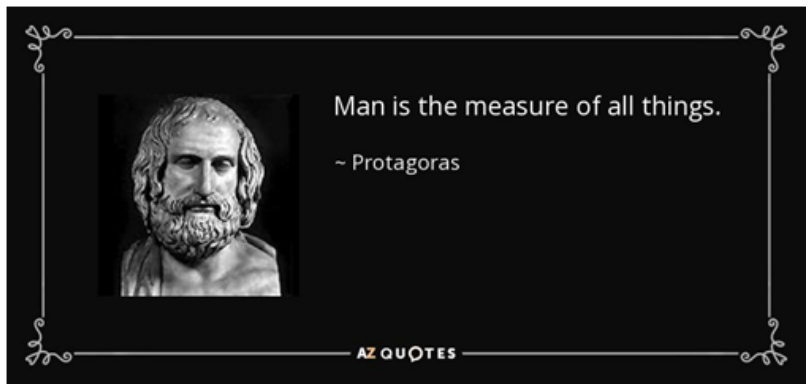

Gambar 1. Protagoras

(Sumber: https://historyancientphilsophy.wordpress.com/2016/04/06/914/) 
Seorang filsuf yang menganggap manusia adalah ukuran segalanya, dengan mengusung ideologi Antropometri (manusia sebagai ukuran). Sehingga segala sesuatu harus menggunakan manusia sebagai alat ukurnya. Prinsip ini kemudian dikenal sebagai salah satu slogan dari relativisme, yakni pandangan bahwa benar atau salahnya suatu argumen, ada atau tidaknya kenyataan tertentu, ditentukan oleh manusia. (Martin Suryajaya 2016:37). Ideologi Protagoras inilah yang melahirkan ide-ide humanisme yang pada tingkatan berikutnya cenderung narsisus. Karakter manusia yang cenderung ingin 'pamer diri', ingin dipuji, menjadi sejalan dengan ideologi Protagoras ini.

Pengembangan dari Antropometri ini, dimana manusia sebagai tolok ukurnya memunculkan teori Ergonomi. Dalam penciptaan produk-produk terapan, ergonomi menjadi faktor yang cukup menentukan. Istilah ergonomi sendiri berasal dari bahasa Yunani, yakni 'ergon' yang berarti kerja dan 'nomos' berarti aturan atau hukum. (Tarwaka, 2004:5). Ergonomi merupakan suatu ilmu, seni dan teknologi yang berupaya untuk menyerasikan alat, cara dan lingkungan, sehingga manusia bisa berkarya secara optimal tanpa pengaruh buruk dari pekerjaannya.

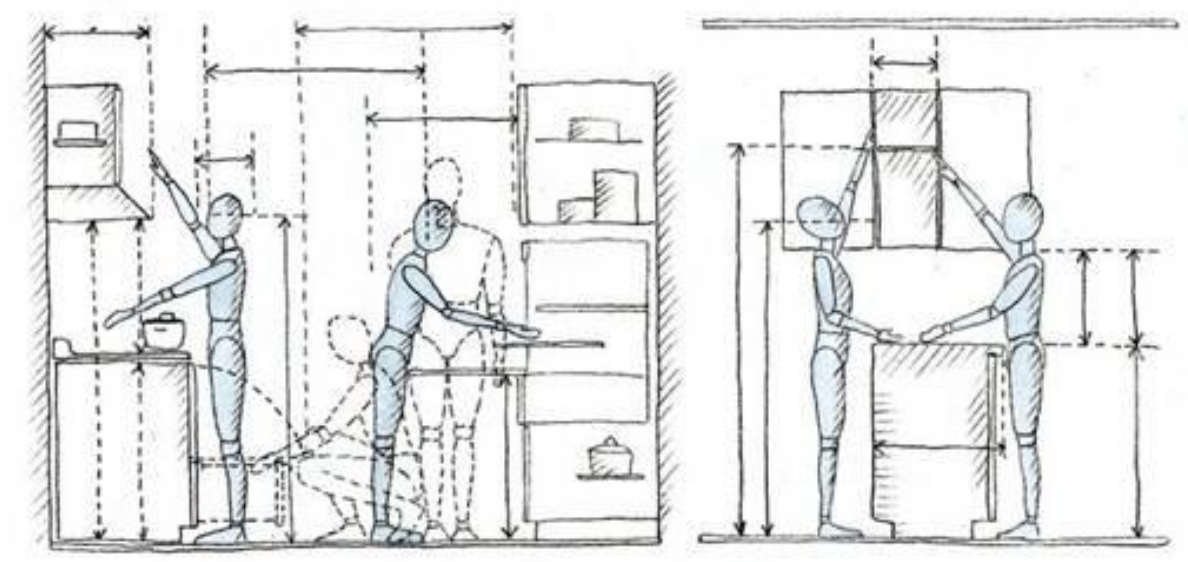

Gambar 2. Ilustrasi mengenai ergonomi.

(Sumber: http://www.vedcmalang.com/ppptkboemlg/index.php/menuutama/mesin-cnc/1129-sonnym)

\subsubsection{Plato (427-347 SM)}

Tokoh kedua ini, menganggap seniman tak lebih dari seorang tukang. Pendapatnya tentang seni harus memiliki 4 (empat) kriteria, menjadi pijakan bagi teori seni dan disain pada periode berikutnya. Plato berpendapat, bahwa sesuatu bisa dianggap sebagai karya seni yang bagus ketika telah memenuhi empat kriteria: 
- Ukuran (proporsi): Karya seni yang tidak mempertimbangkan ukuran (tidak proporsional) dianggap kurang bagus. Bisa ukuran objek seninya, atau perbandingan dengan objekobjek disekitarnya yang menjadi satu kesatuan dalam wujud karya seni.

- Memesis: Semakin mirip sebuah karya seni dengan objek yang ditiru, semakin baguslah karya tersebut. Teori memesis inilah yang menjadi cikal-bakal teknik fotografi, dimana teknik ini mampu meniru objeknya dengan sangat mirip.

- Antusiasme (greget). Sebuah karya seni, menurut Plato haruslah memiliki greget (soul). Pendapat inilah yang kemudian memacu adanya kreativitas, selalu menghadirkan kebaruan.

- Estetis (keindahan). Seni haruslah indah, agar bisa diapresiasi oleh masyarakat. Keindahan ini menjadi cukup penting dalam sebuah karya seni, karena dengan menikmati keindahan tersebut manusia bisa mengembangkan imajinasi dan apresiasinya.

Apa yang dipersoalkan Plato adalah landasan epistemik dari wacana yang disampaikan seniman melalui karya seni. Apabila ternyata sebuah karya tak punya landasan yang memadai, maka karya tersebut layak dicurigai. (Suryajaya, 2016:47).

\subsubsection{Aristoteles}

Menurut Aristoteles, sebuah karya seni tidak cukup berhenti pada keindahan. Karena keindahan itu sendiri, menurutnya harus memiliki tujuan. Karena karya seni terdiri dari Prakton $(d o)$, dimana karya seni harus dimainkan/diperankan atau dilakukan. Karya seni juga merupakan Poetion (make), harus diciptakan atau dibuat dengan tangan. Sehingga muncullah istilah-istilah Pictura Poesies (lukisan adalah puisi), Painting is mute poetry (lukisan adalah puisi tanpa bunyi), Poetry is a speaking picture (puisi adalah suara lukisan). Ada konsekuensi logis yang harus dipikul oleh karya seni ciptaan manusia, yaitu universalitas.

Segala sesuatu yang indah akan bermuara kepada kebenaran, kebenaran itu menentramkan dan menyenangkan dalam kedamaian. Tetapi mengapa terhadap sebuah lukisan, telenovela atau serial drama Korea, sajak dan puisi serta pertunjukan teater, orang sulit sekali bertemu pada satu titik persepakatan bahwa, semua adalah keindahan dan seni (Hadiyatno, 2016:100).

Karya seni juga harus mempertimbangkan fungsi. Sehingga sebuah patung yang akan ditempatkan pada lokasi yang cukup tinggi, maka bagian kepala harus dibuat sedikit lebih besar, untuk mengatasi masalah distorsi. Pada periode ini sebenarnya sudah mulai ditemukan adanya teori perspektif. Fungsi ini menjadi cukup penting, bahkan bisa mengalahkan bentuk itu sendiri (form follow function). 


\subsection{Teori Seni Jaman Pertengahan (Midle Ages)}

Jaman Pertengahan ini juga sering disebut sebagai jaman Gothic atau Jaman Kegelapan (Dark Ages). Disebut sebagai jaman kegelapan karena eksistensi seorang seniman tidak diakui. Karena kuatnya pengaruh Gereja (baca: agama) sehingga keberadaan manusia adalah kepanjangan tangan dari Tuhan. Paham teokrasi, dipahami sebagai intervensi pemuka agama cukup dominan. Seorang seniman tidak diperbolehkan membubuhkan identitasnya dalam setiap karya seni yang dibuatnya. Pendapat Casiodorus bahwa 'pencipta' beda dengan 'pembuat', karena 'pencipta' adalah Tuhan, sedangkan 'pembuat' adalah manusia.

Pada periode ini juga muncul istilah Iconoclasm, dimana karya seni adalah merupakan ikon-ikon yang bermakna, seperti keberadaan Trinitas sebagai simbolisasi dengan makna yang pasti. Muncullah simbol-simbol setan, mahluk bertanduk dan berekor panah dengan memegang trisula sebagai figur yang antagonis dan melawan kebajikan. Demikian juga muncul simbol malaikat yang digambarkan seperti manusia yang memiliki sayap.

Pada jaman ini, karya seni biasanya dikerjakan bersama-sama dengan dijanjikan imbalan sorga. Biasanya bersifat simbolis dan merupakan sebuah alur cerita. Hal ini bisa dilihat misalnya pada arsitektur Katedral yang penuh dengan lukisan/patung dan biasanya meninggi untuk menciptakan efek psiklogis bagi orang yang memasukinya, agar manusia merasa kecil dan lemah.

Seorang Thomas Aquinas berpendapat bahwa keindahan (beauty) haruslah memiliki unsur Integrity (integritas), Proportion/Harmony, dan Clarity (kejelasan). Pemahaman bahwa garis lebih 'jelas' daripada warna memunculkan adanya gesture atau bentuk yang cukup nyata. Pada periode ini juga mulai dikenal adanya teori pencahayan (lighting). Peran cahaya menjadi cukup penting jika dikaitkan dengan clarity, yaitu untuk memperjelas. Cahaya matahari yang bersinar dari atas, adalah dianggap sebagai cahaya sorga atau The light of heaven. Juga digambarkan adanya pancaran cahaya dari tubuh orang-orang yang dianggap suci. Aura atau Mandorla adalah cahaya yang memancar dari seluruh tubuh, sedangkan Halo atau Nimbus adalah cahaya yang memancar dari sekitar kepala.

\subsection{Teori Seni Jaman Renaisans}

Ada yang membagi jaman ini menjadi 3 (tiga) periode, terutama di Eropa dan khusunya di Italia. Abad ke 13 disebut sebagai Tre Cento, abad 14 disebut Quatro Cento dan abad 15 disebut Cinque Cento. Terdapat perbedaan yang cukup jelas dalam karya-karya seni pada Jaman Pertengahan dengan Jaman Renaisans ini. Karya-karya seni pada jaman pertengahan, karena 
landasannya adalah Tuhan, maka sifatnya lebih universal. Tetapi pada Jaman Renaisans, karyakarya seninya lebih individualistik. Sehingga penggambaran terhadap Tuhan oleh masingmasing seniman bisa berbeda-beda, tergantung persepsi mereka.

Seniman Giotto yang hidup pada periode Tre Cento, dalam menggambarkan sesuatu sesuai dengan apa yang dilihatnya. Teori perspektif (cara pandang) pada jaman ini lebih mendapat tempat, termasuk adanya Aerial/Atmospherical Perspective (birds view), Linear Perspective (perspektif horisontal/titik lenyap) dan perspektif berlapis. Giotto juga berani menggambarkan orang dilihat dari belakang, yang sangat tabu pada jaman pertengahan. Garis tidak harus tampak jelas seperti pada jaman pertengahan. Garis semu bisa tercipta karena adanya perbedaan warna (sfumato). Ciri khas lukisan pada jaman ini adalah adanya permainan gelapterang (kontras) yang disebut Ciatro Scurro. Tokoh-tokoh yang telah menorehkan namanya pada lembaran sejarah dunia, antara lain: Tomassi, Donatello, Leonardo da Vinci, Michaelangelo, Raphael.

\subsection{Teori Seni Jaman Barok}

Jaman Barok adalah periode keempat, setelah diawali Jaman Klasik atau Jaman Yunani/Romawi pada periode pertama, kemudian diikuti Jaman Kegelapan (Dark Ages) atau Jaman Pertengahan pada periode kedua, dan periode ketiga yaitu Jaman Renaissance.

Dengan keinginan untuk menentang dominasi Renaisans Akhir, lahir sebuah era bernama Barok (Baroque). Keindahan era ini tampil dengan kekhasan yang tidak rumit, lebih realistis, dan terasa emosional. Keindahan seni masa Baroque itulah yang akhirnya membawa nama besar seperti Rubens, Rembrandt, Vermeer, dan Velazquez terukir dalam kitab besar sejarah dunia.

Jaman Barok yang berlangsung selama tahun 1600-1750 telah banyak mempengaruhi belantika dunia seni. Istilah Barok sendiri menurut beberapa sumber berasal dari dua bahasa, yakni Italia dan Portugal. Dale G. Cleaver dalam bukunya Art: An Introduction menyebutkan, dalam bahasa Italia, barocco berarti “... segala macam sistem pemikiran yang berubah bentuknya, tidak rasional atau tidak murni" (... any system of thought that was conforted, irrational or untrua). Sedangkan dalam bahasa Portugal, barocco berarti “... mutiara yang kasar, belum sempurna" (... a rough, interfect pearl).

Sebenarnya pada akhir abad ke-16, gaya Barok telah muncul di Roma dan menyebar ke Eropa pada dua abad berikutnya. Seni Barok pada awalnya merupakan alat propaganda untuk menghadapi kaum anti perubahan. 
Jaman Barok lahir karena dilatarbelakangi beberapa faktor, pertama karena pengaruh Gereja Katolik yang menggunakan seni sebagai alat propaganda agama. Menurut pandangan gereja, seni bisa memiliki 'makna' jika digunakan untuk kepentingan pemujaan. Faktor kedua adalah pandangan manusia sebagai mahluk sosial (horizon). Sehingga seni berkembang seiring dengan pergerkan ekspansi sosial. Terbukanya dunia baru lewat penjajahan, membawa pula pengaruh seni terhadap daerah jajahannya. Sehingga perluasan gaya Barok ikut serta menyebar ke berbagai penjuru dunia. Ketiga, karena adanya sentralisasi dan stabilisasi politik yang dimotori oleh penguasa-penguasa borjuis.

Kegelisahan Gereja Katolik semakin memuncak ketika tokoh reformis Martin Luther menggelar aksi propagandanya menentang kebijakan gereja. Bentuk protes tersebut melahirkan pemahaman Protestan. Karena pengaruh Protestan tersebut tak dapat dibendung lagi, maka pihak Gereja Katolik mengambil kebijakan menghidupkan kembali 'seni agama'. Tujuannya tentu saja untuk menarik kembali simpati masyarakat (penyembah Tuhan) akan eksistensi gereja. Hal ini mempengaruhi gaya Barok yang lebih ekpresif, impresif, dinamis, serta penuh perasaan dalam merangsang panca indera.

Karena pengaruh agama yang hanya bergerak 'satu arah', berkaitan erat dengan meluasnya pandangan sosial. Pada abad 16-17, penjajahan dan eksplorasi menjadi tujuan dengan prinsipnya yang terkenal dengan 3G, yakni "Gold, God dan Glory" (Emas, Tuhan dan Kejayaan). Emas melambangkan bisnis (dunia usaha), perdagangan. Tuhan melambangkan agama atau gereja. Kejayaan melambangkan jalan keluar untuk membangkitkan semangat dan energi para prajurit dan kaum bangsawan.

Penyebaran gaya Barok oleh penjajah Spanyol, Portugis dan Perancis ini melalui gaya arsitektur, patung, seni lukis dan interior. Gaya Barok masuk ke Indonesia melalui Perusahaan Dagang India Timur (East India Companies) yang dibawa oleh negara-negara non Katolik seperti Belanda dan Inggris.

Ekspansi sosial tersebut juga mempengaruhi dunia ilmu pengetahuan (science), sehingga banyak terjadi kemajuan terutama pada matematika, optika dan ilmu perbintangan (astronomi). Hal ini juga erat sekali hubungannya dengan kelahiran tokoh-tokoh ilmuwan yang sangat terkenal. Seperti Coperwicus (1475-1543), Giordano Bruno (1548-1600), Johannes Kepler (1571-1630), Galileo Galilei (1564-1642), serta Isaac Newton (1642-1727).

Newton selain dikenal sebagai ahli matematika dan ilmu alam, juga terkenal dengan teori warnanya. Untuk memperoleh komposisi warna yang sebanding keluasannya, maka berdasarkan percobaan Newton diperoleh perbandingan keluasan warna sebagai berikut. Untuk keluasan 
warna kuning 3 (tiga) bagian, keluasan warna merah 5 (lima) bagian, dan keluasan warna biru 8 (delapan) bagian. Komposisi warna yang menggunakan perbandingan keluasan warna dengan perbandingan tersebut akan menghasilkan komposisi yang sebanding, artinya memiliki kekuatan yang sama tidak ada yang menonjol. Jika salah satu warna dibesarkan ukurannya maka akan menjadi tidak seimbang dan warna yang perbandingan keluasannya diperbesar akan menjadi menonjol dan mendominasi atau menjadi dominan.

Perbandingan warna-warna lain dapat diperoleh sebagai berikut. Untuk warna jingga, pebandingan keluasananya sama dengan keluasan merah ditambah keluasan kuning adalah 8 (delapan) bagian. Untuk warna hijau, perbandingan keluasannya sama dengan keluasan kuning ditambah biru, adalah 11 (sebelas) bagian. Untuk warna ungu, perbandingan keluasannya sama dengan keluasan warna merah ditambah keluasan warna biru, adalah 13 (tigabelas) bagian.

Kesadaran tentang eksistensi manusia yang teramat kecil jika dibanding alam semesta, memepengaruhi gaya lukisan-lukisan jaman Barok ini. Gambar pemandangan yang dijadikan latar belakang figure manusia dibuat perspektif, semakin jauh objek maka proporsinya semakin kecil, sehingga memberi kesan alam semesta tidak terbatas. Hal ini bisa dilihat pada lukisanlukisan Poussin, Claude dan Ruisdael.

Hal yang sangat penting pada gaya Barok ini juga ditemukan adanya suatu refleksi karakter hidup yang saling berhubungan dengan refleksi ruang dimana dia bergerak. Sehingga dalam arsitektur dan patung gaya Barok, setiap bagian sama pentingnya dengan keseluruhan bentuk/komposisinya.

Dalam karya-karya Rubens, bahkan tidak hanya memperlihatkan konsep homogen dimana terjadi hubungan antara bagian dan keseluruhan, tetapi juga adanya komposisi yang memusat. Seperti halnya planet-planet yang bergerak mengelilingi sebuah objek dalam orbitnya.

Berbicara tentang Jaman Barok tidak bisa lepas dari pengaruh filosof Rene Descartes. Filsafat Descartes tentang 'rasionalisai' dan konsep cogito ergo sum (I think, therefore I exist) Saya berpikir, maka saya ada. Pendekatan rasional tersebut berdampak pada karya-karya seni Jaman Barok. Sehingga semua harus terukur (skeptis).

Pertentangan agama antara Katolik yang dianggap tradisional dengan Protestan yang modern juga berpengaruh pada karya-karya seni pada jaman tersebut. Karya-karya seni pada Jaman Barok lebih berkesan dinamis dibanding karya-karya seni pada jaman sebelumnya (Renaisans). Misalnya tokoh David dalam patung Michael Angelo, lebih statis dan menunggu. Juga lukisan "Perjamuan Terakhir" (The Last Supper) karya Leonardo Da Vinci berkesan monoton, datar, serta formal. 


\subsection{Iklan dan Seni Barat}

Iklan adalah sarana komunikasi di jaman modern yang memiliki tujuan beragam. Mulai dari membangun kesadaran, merubah perilaku, sampai melakukan suatu aksi misalnya pembelian suatu produk. Iklan juga bisa berfungsi sebagai sarana propaganda seperti yang dilakukan oleh Martin Luther pada jamannya yang menentang kebijakan gereja. Kegiatan periklanan sebenarnya sudah dimulai sejak jaman peradaban Yunani kuno dan Romawi kuno. Pada awalnya iklan dilakukan dalam bentuk pesan berantai atau disebut the word of mouth. Setelah manusia mulai menggunakan sarana tulisan sebagai alat penyampai pesan, maka kegiatan periklanan mulai menggunakan tulisan atau gambar yang dipahatkan ke batu, dinding atau pada papan. (Ratna Novianti, 2002:2).

Pada jaman sekarang, berbagai strategi kreatif telah digali oleh desainer-desainer (baca: seniman-seniman) iklan yang bertujuan untuk membujuk atau memprovokasi target audience. Penggalian ide tersebut terus ke dalam, sampai pada abad-abad jaman lampau. Pendekatan cultural, religius mencoba disinergikan dengan karya-karya seni jaman klasik, agar tercipta suasana yang mistis.

Seni Sebagai hasil kreasi budi daya manusia mempunyai bentuk dan corak yang beraneka ragam. Selaras dengan pendapat Kartini Parmono dalam Surajiyo (2015), aliran-aliran dalam seni itu diantaranya: (1) Aliran Naturalisme, bertujuan untuk melukiskan bentukbentuk yang sewajarnya dengan mengindahkan perspektif garis dan warna serta anatominya; (2) Aliran Ekspresionisme, melukiskan jiwa objek atau pendapatnya tentang jiwa objek, cara memaknakan ide itu terlepas dari pengaruh yang kebetulan ada dan disadurkan untuk dapat mencapai inti kerokhaniannya; (3) Aliran Impressionisme, melukiskan kesan alam yang diterima dengan spontan, cepat dan pasti bagian yang kecil-kecil tidak diindahkan, yang dipentingkan keseluruhannya hingga suasana bentuk, gerak dan sinar itu dilukiskan tidak terpisah.

Beberapa iklan berikut mencoba menggunakan pendekatan klasik tersebut untuk dihadirkan kembali di jaman sekarang. Muatan-muatan pesan komersial maupun sosial dibubuhkan dalam modifikasi karya-karya seni jaman klasik.

\subsubsection{The Last Supper (Perjamuan Terakhir)}

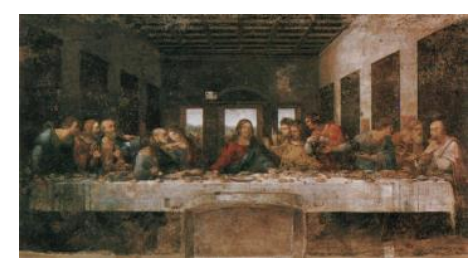

Gambar 3. The Last Supper karya Leonardo Da Vinci

(Sumber: https://www.engadget.com/2017/07/25/the-last-supper-eataly-conservation-project-art-restoration/) 
Mahakarya Leonardo Da Vinci dari Jaman Renaisans ini telah mengilhami beberapa pekerja kreatif periklanan. Prinsip formal balance serta Symmetry yang terdiri dari formasi 6 orang murid Yesus di sebelah kiri, Yesus sendiri yang berada tepat ditengah dan 6 orang murid lagi di sebelah kanan, oleh sebuah iklan fashion telah dirubah keseimbangannya. Iklan Marithe \& Francois Girbaud telah 'mencuri' The Last Supper-nya Leonardo Da Vinci untuk mempromosikan produknya.

Dengan komposisi figur 6-1-6 masih tetap dipertahankan, namun sosoknya telah digantikan oleh sekelompok wanita, dan yang menjadikan iklan ini sangat kontroversial, karena isu 'penghianatan' murid Yesus dengan sangat vulgar digatikan dengan isu 'perselingkuhan'. Hal ini sangat jelas terlihat pada sosok seorang laki-laki tanpa baju memeluk mesra salah satu wanita yang berada di sebelah kiri. Lukisan The Last Supper yang begitu sakral telah mengalami proses desakralisasi dalam iklan ini.

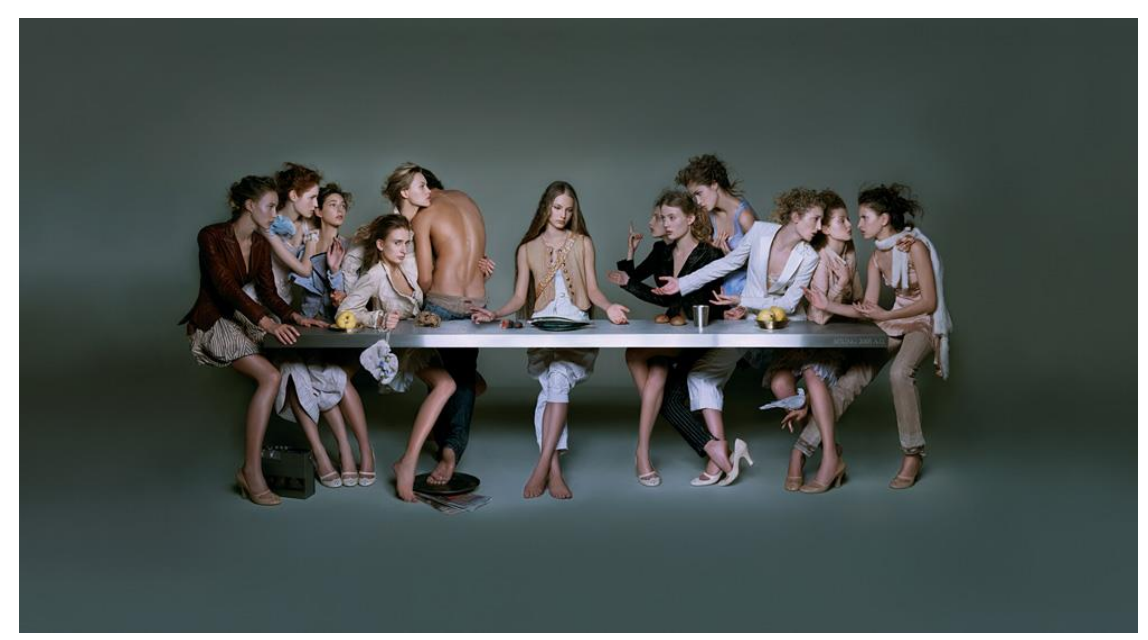

Gambar 4. Iklan Marithe \& Francois Girbaud.

Sumber: http://theinspirationroom.com/daily/2007/last-supper-in-advertising/

Produk fashion Marithe \& Francois Girbaud mencoba membangun citra 'agung' dan eksklusif seperti karya Da Vinci tersebut, walaupun iklan ini pada akhirnya menuai protes yang cukup keras karena 'keberaniannya' tersebut. Marithe dan Francois Girbaud mendesain ulang "Perjamuan Terakhir" dalam iklan mereka untuk jeans, digambarkan dalam foto tersebut sebagian besar adalah wanita, dengan billboard yang diluncurkan pada Maret 2005, karakter John digambarkan sebagai satu-satunya pria, mengenakan jins dan telanjang dari pinggang ke atas.

Tanggapan pertama datang dari kota Milan, rumah dari Da Vinci. Pengadu mengatakan bahwa gambar itu menyinggung kepekaan agama semua warga negara. Mereka mengklaim 
bahwa iklan tersebut meremehkan momen yang penting dan dramatis selama "Perjamuan Terakhir" di mana Kristus mengantisipasi penyalibannya untuk membebaskan umat manusia dari dosa-dosa mereka dengan menyesuaikan simbol-simbol keagamaan seperti roti dan ikan untuk tujuan komersial dan dengan mengganti para rasul dengan perempuan sebagai model.

Marithe dan Francois Girbaud menanggapi dengan mengatakan bahwa masyarakat modern telah memungkinkan perempuan untuk mencapai kesetaraan seksual dengan laki-laki hanya dengan mengorbankan kewanitaan mereka. Interpretasi iklan lukisan Leonardo ini tidak meremehkan yang sakral, tetapi menciptakan persepsi baru tentang feminitas dengan menghadirkan laki-laki dan bukan perempuan dalam posisi rapuh.

Iklan dengan menggunakan objek lukisan Da Vinci tersebut juga dilakukan oleh Biro Iklan Ogilvy Indonesia. Sebenarnya iklan layanan masyarakat (ILM) ini bertujuan baik, yaitu himbauan untuk mematikan handphone saat berada di Gereja.

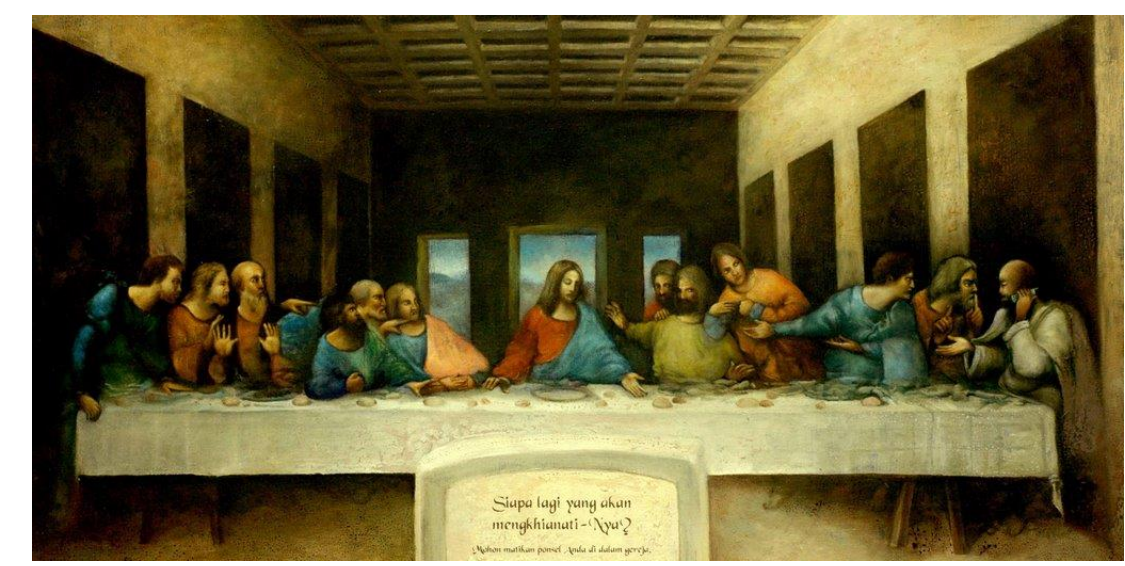

Gambar 5. Iklan Ogilvy Indonesia himbauan mematikan handphone saat di Gereja. (Sumber: https://www.adsoftheworld.com/forum/exhibition/last_supper)

Dengan headline "Siapa lagi yang akan menghianati-Nya?" dan body copy "mohon matikan ponsel Anda di dalam Gereja", iklan ini ingin mengingatkan para jemaat untuk menghormati peribadatan/misa dengan jalan mematikan ponsel (handphone) nya. 'Pesan Moral' ini diperkuat dengan visualisasi seorang murid di ujung kanan meja sedang melakukan aktifitas komunikasi menggunakan ponsel. Juga ekspresi murid-murid lain yang berkesan 'terganggu' dengan ulah murid di ujung kanan tersebut.

Berbeda dengan pendekatan 'citra' pada iklan fashion diatas, iklan layanan masyarakat ini menggunakan pendekatan 'humor' tapi 'serius'. Tak urung iklan inipun menuai protes dari berbagai kalangan, karena dituduh telah melakukan desakralisasi The Last Supper, lebih dari itu juga menerima tuduhan telah melakukan humorisasi Gereja. 


\subsubsection{Adam and Eve}

Adam \& Eve (Adam dan Hawa) sebagai Bapak dan Ibu seluruh manusia di dunia, cukup populer menjadi objek lukisan sejak jaman klasik hingga sekarang. Mengingat sosok Adam dan Eva adalah sosok yang tak pernah seorangpun dijaman klasik apalagi sekarang yang pernah berjumpa dengannya, maka penggambaranya pun disesuaikan dengan imajinasi senimannya. Sehingga sosok Adam dan Hawa pada jaman Romawi atau jaman klasik sesudahnya adalah sebuah figur manusia dengan anatomi agak gemuk, rambut keriting, tanpa busana dan hanya menggunakan dedaunan untuk menutupi organ genetikalnya.

Penggambaran sepasang manusia pertama tersebut diatur dalam suasana surga yang penuh buah-buahan dan binatang jinak. Iblis sang penggoda divisualkan sebagai seekor ular yang licik, untuk menggoda sepasang manusia tersebut agar melanggar larangan Tuhan.

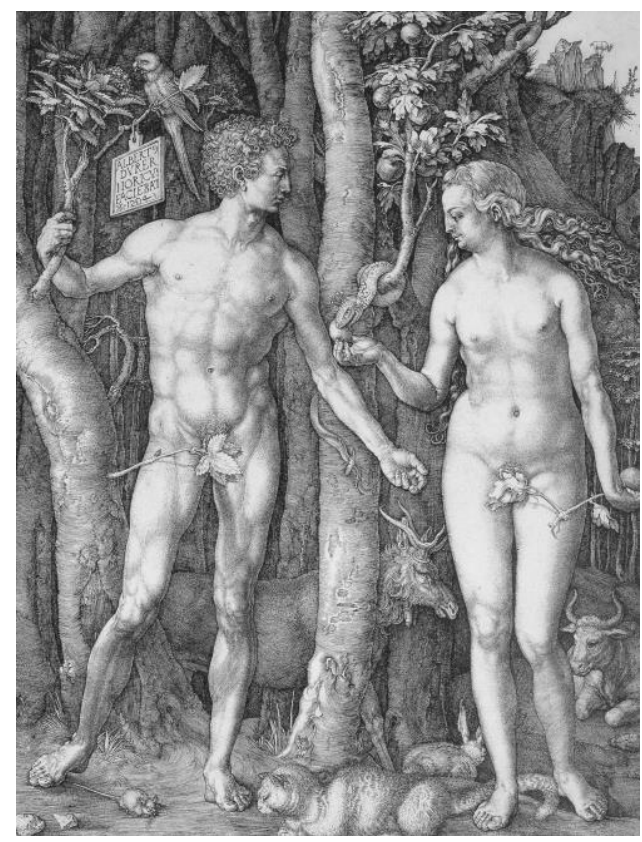

Gambar 6. Ilustrasi Adam dan Hawa

(Sumber: http://www.marcovermeulen.eu/office/23/workshops/6/1000m3paradise/79/english/)

Sepasang manusia berlawanan jenis apalagi tanpa busana, maka persepsi orang mengarah pada aktivitas seksual, kesepakatan umum inilah yang dimanfaatkan oleh sebuah produsen kondom merek Durex untuk menyampaikan pesan komersialnya. Lukisan Adam dan Hawa adalah karya seni yang melegenda, dari generasi ke generasi. Sinergi dari dua unsur (aktifitas seks dan legenda) yang muncul dalam karya seni Adam dan Hawa dimanfaatkan oleh Durex dengan cukup kreatif. Adam dengan penutup kelamin dari selembar daun yang lebar, sementara Hawa dengan penutup daun yang lebih kecil, ada unsur 'humor logika' di sini . 


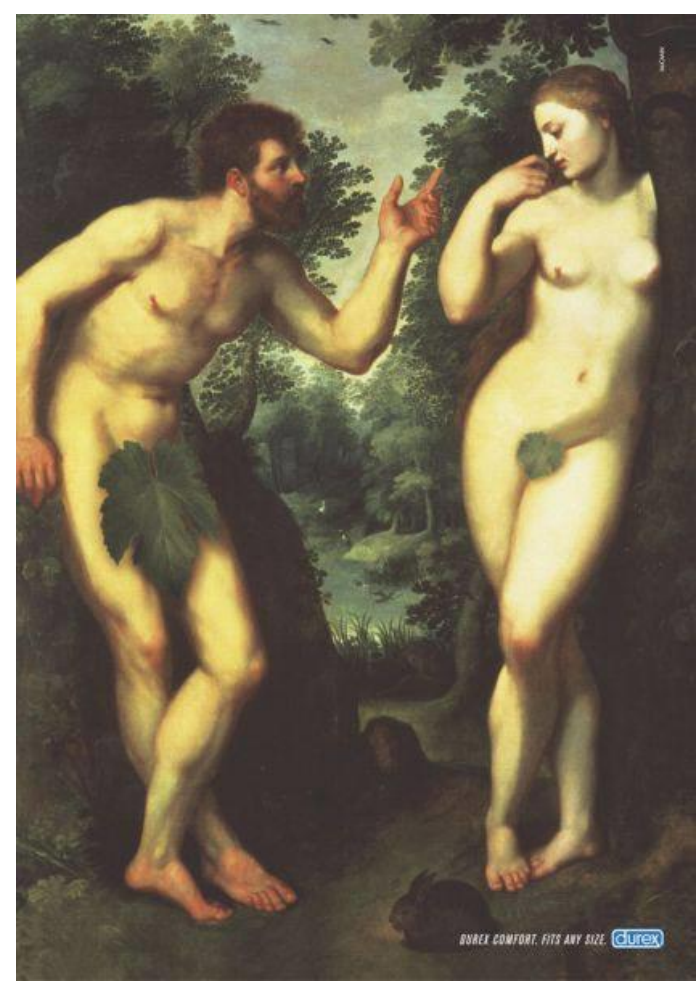

Gambar 7. Ilustrasi Adam dan Hawa dalam iklan Durex

(Sumber: http://www.advertisingtimes.fr/2012/05/adam-et-eve-entre-tentation-et.html)

Dengan headline "Durex Comfort, Fits Any Size" iklan ini mencoba bertutur tentang produk kondom Durex Comfort fleksibel untuk segala ukuran (kelamin pria). Hal ini diperkuat dengan visualisasi daun penutup kelamin Adam yang cukup lebar dan sangat kontras dengan ukuran daun penutup kelamin Eva. Iklan ini juga dapat bermakna bahwa produk kondom Durex adalah 'pemain' lama untuk jenis produk kondom, sehingga penggunaan lukisan Adam \& Hawa yang digunakan untuk mengkomunikasikan produk Durex Comfort berkesan produk yang legendaris.

\subsubsection{Iklan HIV AIDS Versi Makam}

Iklan layanan masyarakat tentang bahaya HIV AIDS yang dipersembahkan oleh Quebec ini mengingatkan kita pada patung-patung karya seni Jaman Renaisans. Tiga versi iklan di atas yang berupa patung sedang melakukan aktivitas yang cenderung menularkan virus HIV. Patungpatung tersebut berada pada lokasi pemakaman yang sepi. Iklan-iklan tersebut bertutur tentang aktifitas seperti yang tergambar dalam patung-patung tersebut, sangat mungkin menularkan atau bahkan menjangkitkan virus HIV yang sangat mematikan. Sehingga penempatan patung-patung tersebut di atas altar pemakaman, mampu membangkitkan imajinasi tentang kematian akibat serangan virus HIV AIDS. 

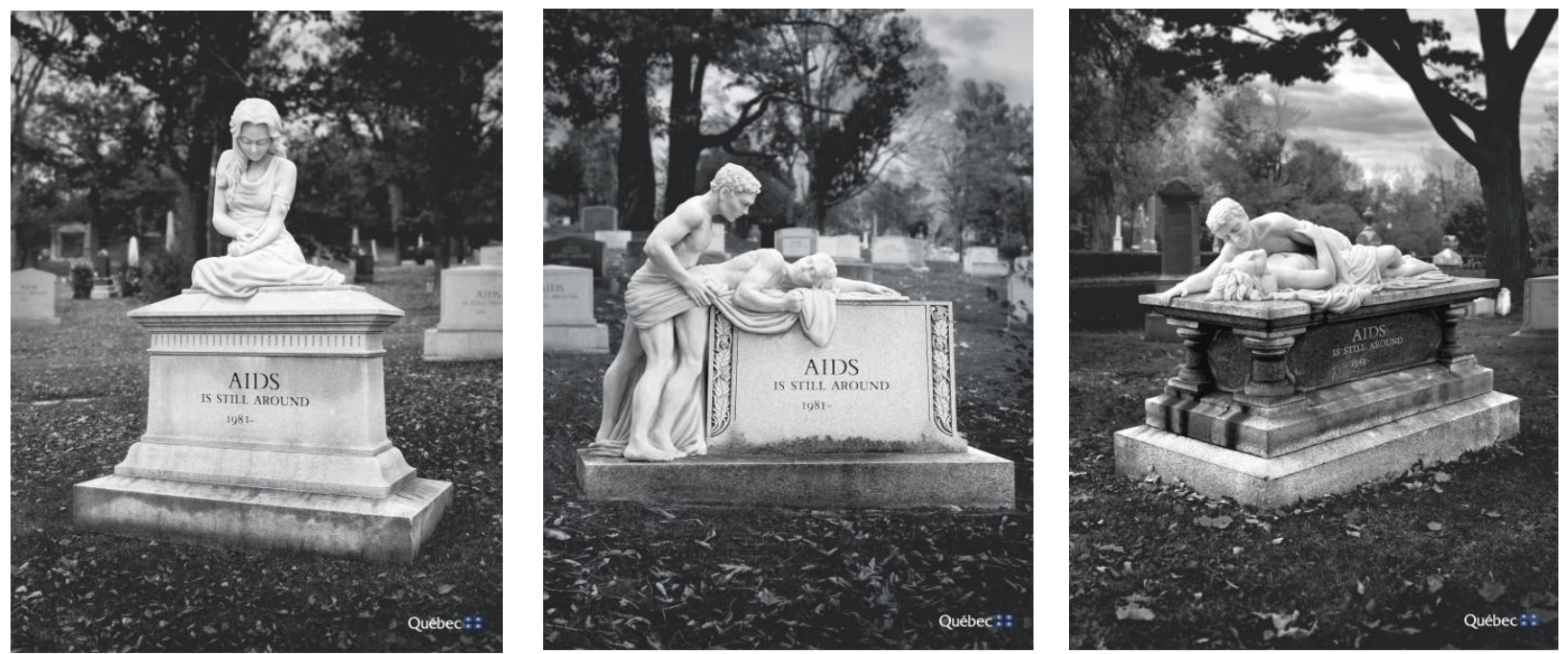

Gambar 8. Iklan Quebec.

(Sumber: http://www.adeevee.com/2003/11/quebec-health-and-social-services-department-aids-awareness-girl-manand-woman-man-and-man-print/)

\section{KESIMPULAN}

Perkembangan dunia disain komunikasi visual dan advertising yang sangat dinamis, memungkinkan penggalian-penggalian karya seni Jaman Klasik, Jaman Pertengahan, Jaman Renaisanse maupun Jaman Barok untuk dihadirkan kembali dalam konsep kekinian. Lepas dari apakah iklan-iklan tersebut telah melanggar norma sakralisasi karya seni atau tidak, yang jelas 'materi-materi terpendam' yang berupa mahakarya seniman-seniman bersejarah tersebut juga bisa di'jarah' oleh dinamika kreativitas disain komunikasi visual maupun advertising.

Kita yang hidup dijaman modern seperti sekarang ini, tetap tidak bisa menampik jasa-jasa seniman besar pengukir peradaban. Prinsip-prinsip disain seperti: komposisi, ritme, warna, unity, clarity, dan sederet prinsip-prinsip lain sebenarnya merupakan kelanjutan dari pondasi prinsip tata rupa yang telah diletakkan oleh seniman-seniman besar tersebut. Sehingga teori-teori seni yang berkembang sampai saat inipun, pada prinsipnya juga teori-teori seni yang sudah diterapkan oleh Plato, Aristoteles, Da Vinci, Michael Angelo, Descartes, Rubens dan lain-lain.

Memang untuk bisa senantiasa menampilkan unsur kebaruan dalam disain komunikasi visual, dibutuhkan kepekaan budaya yang cukup tajam. Agar 'bahan baku' yang sudah disediakan oleh seniman-seniman besar tersebut mampu diresnpons positif oleh desainer modern. Pada gilirannya akan diproses dan dihadirkan dalam karya seni disain yang sesuai dengan jamannya. 


\section{DAFTAR PUSTAKA}

Hadiyatno., 2016. Menyoal kehadiran Keindahan dan Seni. Jurnal Pendidikan dan Kajian Seni, Vol. 1. No. 2. Oktober. Hal: 95-106.

Noviani, Ratna. 2002. Jalan Tengah Memahami Iklan. Antara Realitas, Representasi dan Simulasi. Yogyakarta: Pustaka Pelajar.

Surajiyo., Keindahan Seni Dalam Perspektif Filsafat. Jurnal Desain, Volume 02, No. 03, Mei 2015. Hal: 157-168.

Suryajaya, Martin., 2016. Sejarah Estetika. Jakarta Barat: Gang Kabel.

Tarwaka, Solichul HA, dkk., 2004. Ergonomi Untuk Keselamatan, Kesehatan Kerja dan Produktivitas. Surakarta: Uniba Press.

https://historyancientphilsophy.wordpress.com/2016/04/06/914/. Diakses pada 12 Januari 2018.

http://www.vedcmalang.com/pppptkboemlg/index.php/menuutama/mesin-cnc/1129-sonnym. Diakses pada 12 Januari 2018.

http://theinspirationroom.com/daily/2007/last-supper-in-advertising/. Diakses pada 12 Januari 2018.

https://www.adsoftheworld.com/forum/exhibition/last_supper/. Diakses pada 12 Januari 2018.

http://www.marcovermeulen.eu/office/23/workshops/6/1000m3paradise/79/english/. Diakses pada 12 Januari 2018.

http://www.advertisingtimes.fr/2012/05/adam-et-eve-entre-tentation-et.html. Diakses pada 12 Januari 2018.

http://www.adeevee.com/2003/11/quebec-health-and-social-services-department-aidsawareness-girl-man-and-woman-man-and-man-print/. Diakses pada 12 Januari 2018.

https://www.engadget.com/2017/07/25/the-last-supper-eataly-conservation-project-artrestoration/. Diakses pada 12 Januari 2018. 